\title{
Cheneau bracing with dobomed physiotherapy for thoracic scoliosis: prospective evaluation of 25 patients followed to skeletal maturity
}

\author{
Jacek Durmala*, Thomasz Kotwicki, J Piotrowski \\ From 7th International Conference on Conservative Management of Spinal Deformities \\ Montreal, Canada. 20-22 May 2010
}

\section{Introduction}

Giving evidence of efficacy of conservative management of progressive idiopathic scoliosis in the period of rapid adolescent growth requires prospective evaluation and a long time observation, thus the final number of patients available for analysis is often limited.

The aim of the study was to present a series of patients who finished the conservative treatment.

\section{Material and methods}

Twenty-five girls aged 10 to 14 years underwent conservative treatment for thoracic idiopathic scoliosis. All revealed radiological proof of progression. The initial thoracic Cobb angle revealed the value of $16.0^{\circ}$ to $40.0^{\circ}$, mean $26.1^{\circ} \pm 8.4^{\circ}$. Cheneau brace was ordered for full time wearing, accompanied with DoboMed daily physiotherapy. The treatment was endorsed during a 2 week in-patient stay at the rehabilitation department; the brace was fitted and the patients learned physiotherapy. Regular controls were performed with a radiological check once a year. The duration of therapy was 36 to 89 months, mean $53.6 \pm 14$ months. The last radiography was done 6 months after discharging from brace.

\section{Results}

The effective time of brace wearing reported on investigation varied from 8 to 23 hours, mean $11.9 \pm 5.5$ hours. The Cobb angle at follow-up was $8.0^{\circ}$ to $54.0^{\circ}$, mean $32.0^{\circ} \pm 12.7^{\circ}$. The stabilization was achieved in $56 \%$ of patients. Three patients $(12 \%)$ exceeded the value of $50^{\circ}$ of Cobb, considered to be surgical indication.

University of Medical Sciences, Poznan, Poland

Full list of author information is available at the end of the article

\section{Conclusion}

Stabilization of progressive thoracic scoliosis was achieved in girls using the Cheneau brace and specific DoboMed physiotherapy.

Published: 10 September 2010

doi:10.1186/1748-7161-5-S1-075

Cite this article as: Durmala et al:: Cheneau bracing with dobomed physiotherapy for thoracic scoliosis: prospective evaluation of 25 patients followed to skeletal maturity. Scoliosis 2010 5(Suppl 1):075.
Submit your next manuscript to BioMed Central and take full advantage of:

- Convenient online submission

- Thorough peer review

- No space constraints or color figure charges

- Immediate publication on acceptance

- Inclusion in PubMed, CAS, Scopus and Google Scholar

- Research which is freely available for redistribution

Submit your manuscript at www.biomedcentral.com/submit
C Biomed Central 